https://doi.org/10.30910/turkjans.633614

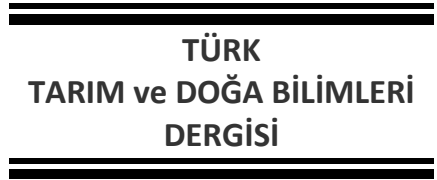

www.dergipark.gov.tr/turkjans

\title{
Hatay ilinde Domates Bitkilerinden Elde Edilen Pyrenochaeta lycopersici izolatlarının Virülens Düzeyleri ve Moleküler Tiplerinin Belirlenmesi
}

TURKISH

JOURNAL Of AGRICULTURAL

and NATURAL SCIENCES

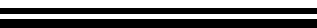

Fatih Mehmet TOK*

Hatay Mustafa Kemal Üniversitesi, Ziraat Fakültesi, Bitki Koruma Bölümü, Antakya/Hatay.

*Sorumlu Yazar: ftok@mku.edu.tr

Geliş Tarihi: 05.08.2019

Düzeltme Geliş Tarihi: 10.09.2019

Kabul Tarihi: 10.09.2019

Özet

Steril fungus olarak da bilinen Pyrenochaeta lycopersici, domates yetiştiriciliği yapılan ılıman iklim kuşağındaki pek çok alanda, \%40-70 arası ürün kaybına sebep olan önemli bir patojen fungustur. $P$. lycopersici tarafından oluşturulan domates mantarımsı kök hastalığının etkin kimyasal mücadelesi bulunmamaktadır. Bu çalışmada, Hatay ilinde domates yetiştiriciliği yapılan alanlardan elde edilen $P$. lycopersici izolatlarının virülens düzeyleri ve moleküler tipleri araştııımıştır. 2015 yılında Hatay iline bağlı domates yetiştirilen alanlarda survey çalışmaları gerçekleştirilmiş ve bu esnada solgunluk, sararma ve kök çürüklüğü görülen bitkilerden örnekler alınmıştır. Yarı seçici besi ortamında yapılan izolasyonlarda 17 P. Iycopersici izolatı elde edilmiş ve teşhisleri ITS1/4 sekansı ile moleküler olarak doğrulanmıştır. Plyc1 ve Plyc2 spesifik primerleri ile yapılan PCR işlemi sonrasında izolatların 3'ünün moleküler Tip1 ve 14'ünün ise Tip2 olduğu tespit edilmiştir. Domates fideleri ile kültür filtrat yöntemi kullanılarak patojenisite testi gerçekleştirilmiştir. Oluşan hastalık simptomları 0-4 skalası kullanılarak değerlendirilmiş ve skala değerleri McKinney formülü kullanılarak McKinney indeksi değerlerine dönüştürülmüştür. Patojenisite testi sonucunda hastalık şiddeti izolatlar arasında farklılık göstermiştir (65-95). Moleküler tip ile izolatların virülenslikleri arasında herhangi bir ilişki bulunmadığı ancak izolatların elde edildikleri lokasyon ile virülenslikleri arasında hafif bir ilişkinin bulunduğu tespit edilmiştir.

Anahtar kelimeler: Domates, mantarımsı kök, Pyrenochaeta, virülens, Hatay.

\section{Variability of Virulence and Molecular Types in Pyrenochaeta lycopersici Isolates From Tomato in Hatay Province of Turkey}

\begin{abstract}
Pyrenochaeta lycopersici is one of the most important fungal plant pathogen, which is known as sterile gray fungus on tomato and causes severe yield loss up to $40-70 \%$ in most of the temperate tomato growing areas. There is no effective chemical control methods of corky root of tomato caused by $P$. lycopersici. In this study, we examined variability of virulence and molecular types in $P$. lycopersici isolates from tomato in Hatay province of Turkey. In 2015, surveys were carried out in tomato growing areas of Hatay province of Turkey and infected plant samples showing wilting, yellowing and root rot symptoms were collected. After isolations on semi selective medium, a total of 17 Pyrenochaeta lycopersici isolates were collected and verified by ITS1/4 sequence. PCR process with Plyc1 and Plyc2 specific primers showed that 3 isolates were molecular Type1 and 14 isolates were Type2. To assess of virulence level of Pyrenochaeta lycopersici, a pathogenicity test was conducted with tomato seedlings by culture filtrate method. Disease symptoms were measured with a scale of 0-4 and the index were transformed to McKinney index. According to McKinney index, disease severity varied among isolates (65 to 95). There was no relationship between molecular types and virulence level but we detected slight relationship between location and virulence in this study.
\end{abstract}

Keywords: Tomato, corky root, Pyrenochaeta, virulence, Hatay. 


\section{Giriş}

Çekirdekleri olduğu için meyve mi yoksa sebze mi olduğuna dair tartışmalar olmakla birlikte, domates aslında bilimsel adı Solanum lycopersicum olan, pek çok ülkenin mutfağında kullandığı, dünya çapında yaygın, çekirdekli, yenebilen bir meyvedir. Sofrada yaş olarak ya da yemeğin içinde kullanılmasının yansıra, bu miktarın çok daha fazlası ketçap endüstrisinde kullanılmaktadır. Aslında domatesin ana vatanı Orta ve Güney Amerika'dır ancak günümüzde ılıman iklim kuşağında ve sera ortamında pek çok çeşitle yıl boyu üretimi yapılmaktadır (Nicola ve ark., 2009). Günümüzde yıllık taze domates üretim miktarı 160 milyon tona ulaşmış durumdadır (FAO, 2017). Dünyadaki yıllık üretim miktarlarına göre, Çin 59.514.773 ton ile birinci sırada, Hindistan 20.708.000 ton ile ikinci sırada, Türkiye ise 12.750 .000 ton ile üçüncü sırada, ABD 10.910.990 ton ile dördüncü, Mısır ise 7.297.108 ton domates üretimi ile beşinci sırada yer almaktadır (FAO, 2017). Ülkemizde 2018 yılında, salçalık ve sofralık olmak üzere toplamda 12.150.000 ton domates üretimi gerçekleşmiş olup bu üretimin 97.543 tonu Hatay ilinde yapılmıştır (TÜiK, 2018).

Domates bitkisinde, antraknoz, kurşuni küf, solgunluklar, kök ve kök boğazı çürüklükleri, çökerken, erken ve geç yaprak yanıklıkları gibi pek çok fungal hastalık görülmekle birlikte (Carling ve ark., 1992; Retig ve ark., 1973; Rowe ve ark., 1995; Sherf ve ark., 1986; Young ve ark., 1940) bunlardan en önemlilerinden birisi de Pyrenochaeta lycopersici'nin sebep olduğu mantarımsı kök çürüklüğü hastalığıdır (White and Scott, 1973). Gri steril fungus olarak da adlandırılan Pyrenochaeta lycopersici, Asya, Avrupa, Amerika ve Avustralya kıtalarında, aralarında Türkiye'nin de bulunduğu 35 farklı ülkede görülen, dünya çapında yaygın bir domates patojeni fungustur (Cabi ve Eppo, 2019). Eşeyli dönemi bilinmeyen etmenin koyu renkli piknitleri ve içerisinde bölmeli ve dallanmış konidioforları üzerinde bölmesiz konidiosporları ile tanınırlar (Schneider ve Gerlach, 1966). Piknitler doğal enfekteli dokularda görülmezler ve laboratuvar şartlarında da nadiren oluşurlar. Bu sebeple konidilerin hastalığın yayılmasındaki rolü yok denecek kadar azdır. P. lycopersici, topraktaki bitki artıkları üzerinde farklı şekil ve büyüklükte oluşturduğu mikrosklerotlar halinde olumsuz şartları geçirir (White ve Scott, 1973). Hastalık etmeni toprak kökenli patojen bir fungus olup domatesin yanısıra biber, patlıcan, kavun ve hıyar gibi diğer Solanaceae ve Cucurbitaceae familyasından bitkilerde de hastalık oluşturabilmektedir. Ancak diğer bazı bitkilerde hastalık oluşturmasına karşın domateste daha şiddetli ve daha yaygın mantarımsı kök çürüklüğü oluşturduğu bilinmektedir (Grove ve Champbell, 1987; Schneider ve Gerlach, 1966).

P. lycopersici'nin sebep olduğu mantarımsı kök çürüklüğü görülen bitkiler genellikle bodur ve güçsüz kalırlar. Hastalık ilerledikçe gün ortası sıcak saatlerde solgunluk başlar ve daha sonraları solgunluk kalıc hale gelir. Ilerleyen zamanlarda yapraklar erken dökülmeye başlar ve dökülmeyen yapraklarda kloroz gözlenir. Kök bölgesinde görülen ilk simptomlar, ince köklerde meydana gelen küçük eliptik kahverengi lezyonlardır. Hastalığın daha ileri safhalarında daha kalın kökler de enfekte edilir ve kahverengileşen kök alanı genişler. Bu kahverengileşen köklerde şişkinlikler ve boyuna çatlamalar meydana gelir ki bu çatlaklar kök bölgesine mantarımsı bir görünüm verir. $\mathrm{Bu}$ aşamada ince ve kılcal köklerin tamamı çürür ve kök, kök boğazı ve gövdenin başlangıç kısmı tamamen kahverengine döner. Olgun bitkilerdeki dallar uç bölgeden başlayıp sona doğru kuruma gösterirler. Bu tarz hasta bitkilerde meyve verimi olmaz ya da yok denecek kadar azdır (Goodenough ve Maw, 1973; Pohronezny ve Volin, 1991) ve bu hastalıktan dolayı ürün kaybının \%40-70 arası olabileceği bildirilmiştir (Workneh ve ark., 1993).

Hastalıkla mücadelede toprak fumigasyonu ve bu hastalığa dayanıklı bitkiler üzerine aşılama yöntemleri önerilmektedir ancak toprak fumigasyonunun geniş alanlarda uygulanamaması, metil bromid kadar etkin bir fumigantın bulunamamış olması ve aşılama için dayanıklı anaç bulunmaması hastalıkla mücadeleyi oldukça zorlaştırmaktadır. Günümüzde hastalığa dayanıklı çeşit bulunmamaktadır. Trichoderma viride, Streptomyces spp. ve Bacillus subtilis'in laboratuvar şartlarında etkinlikleri bilinmesine karşın henüz hastalığa karşı ruhsatlı bir kimyasal bulunmamaktadır (Fiume ve Fiume, 2008). Bir hastalıkla mücadele edebilmek için o hastalığı oluşturan etmeni iyi tanımak ve onun biyolojik, fizyolojik, patojenik özelliklerini iyi tanımlamak gerekir. Bu bilgilerin önceden edinilmesi, hastalığa karşı mücadele stratejilerinin geliştirilmesinde katkı sağlar. Diğer bir ifade ile, düşmanı tanımak mücadeleyi kolaylaştırır. $P$. lycopersici besi ortamında büyüme oranı, rDNA'nın ITS bölgesindeki sekansları, AFLP ve RAPD gibi markırlar ile oluşturdukları bantların farklılıklarına göre moleküler Tip1 ve Tip2 olarak sınıflandırılmaktadır (Sugiura ve ark., 2003; Infantino ve Pucci, 2005; Pucci ve ark., 2011). Fungusun rDNA-ITS sekansı karşılaştırıldığında iki tip arasındaki benzerlik \%8990 olurken grupların kendi içlerindeki benzerlik \%99-100 olarak bildirilmiştir (Infantino ve Pucci, 2005). Dünyada ve ülkemizde $P$. lycopersici izolatlarında virülenslik ve moleküler tiplerin belirlenmesi ile ilgili yapılmış bazı çalışmalar mevcut 
(Bayraktar ve Oksal, 2011; Infantino ve Pucci, 2005; Infantinoa ve ark., 2015; Fiume ve Fiume, 2008) olmasına karşın Hatay ilinde konu ile ilgili yapılmış herhangi bir çalışma bulunmamaktadır.

Bu çalışmanın amacı, Hatay ilinde domates yetiştiriciliği yapılan alanlardan elde edilen $P$. lycopersici izolatlarının virülens düzeylerinin ve moleküler tiplerin belirlenmesidir.

\section{Materyal ve Yöntem \\ izolatların elde edilmesi ve tanımlanması}

2015 yılı yaz ve kış aylarında, Hatay ili'ne ait örtü altı ve açık alanda domates yetiştiriciliği yapılan alanlarda survey çalışmaları gerçekleştirilmiştir. Bu esnada solgunluk, sararma, yaprak dökümü, kök boğazında çatlama ve kahverengileşme ile kök bölgesinde kahverengi çürüme görülen domates bitkilerinin kök ve kök boğazını içerecek şekilde örnekler alınarak plastik poşetlere koyulmuş, etiketlendikten sonra buz kutusuna alınarak izolasyon işlemi gerçekleştirilene kadar $+4{ }^{\circ} C^{\prime}$ de saklanmıştır. Enfekteli bitki dokuları, dış kısımları bistüri yardımı ile uzaklaştırıldıktan sonra küçük parçalara ayrılmış ve \%1'lik sodyum hipoklorit (NaOCl) çözeltisinde yüzeyden sterilize edildikten sonra besi ortamına aktarılmıştır. İzolasyonlarda Tamietti ve Valentino (1990)'nun P. lycopersici'nin izolasyonu için önermiş oldukları yarı seçici besi ortamı ve Grove ve Campbell (1987)'in önermiş oldukları besi ortamları kullanılmıştır. İzolasyondan 7 gün sonra, gelişen fungal koloniler öncelikle Schneider ve Gerlach (1973)'ın önermiş oldukları morfolojik yöntemlerle teşhis edilmiştir.

\section{Moleküler teşhis ve tip belirleme}

İzolatlara ait DNA'lar DNeasy Plant Mini Kit

(Qiagen) kullanılarak ekstrakte edilmiştir. Moleküler yöntemle teşhis amacıyla morfolojik olarak $P$. lycopersici olduğu düşünülen izolatlar arasından temsili bazı izolatların fungal rDNA'ya ait ITS bölgesi ITS1 (5'-TCCGTAGGTGAACCTGCGG-3') ve ITS4 (5'TCCTCCGCTTATTGATATGC-3') primerleri kullanılarak White ve ark. (1990)'nın önerdikleri yönteme göre amplifiye edilmiştir. PCR karışımında her bir primerden $0.5 \mu \mathrm{M}, 10 \mu \mathrm{M}$ DNTP, $1.5 \mathrm{mM}$ $\mathrm{MgCl}^{2}$ ve $1 \times$ tampon (Fermantas) içerecek şekilde oluşturulmuştur. PCR döngüsü; $94^{\circ} \mathrm{C}^{\prime}$ de 2 dakika denatürasyonun ardından 35 döngü $94^{\circ} \mathrm{C}^{\prime}$ de 1 dakika, $55.5^{\circ} \mathrm{C}^{\prime}$ de 2 dakika ve $72^{\circ} \mathrm{C}^{\prime}$ de 2 dakika, ve son olarak $72^{\circ} \mathrm{C}^{\prime}$ da 10 dakika olarak uygulanmıştır. Amplifiye edilen DNA parçaları ticari bir firmaya her iki yönden sekans ettirilmiş ve elde edilen very BLAST analizine tabi tutulmuş ve böylelikle izolatların moleküler teşhisi yapılmıştır.

P. lycopersici'nin moleküler tiplerini belirlemek amacıyla Infantino ve Pucci (2005)'nin önerdikleri ve rDNA-ITS bölgesine göre dizayn edilmiş ve Tip1'e spesifik Plyc1 (F:5'GTAGGATTGCGTGCTTTGGT-3' R:5'AGTTTTCTGACGCTGATTGC-3') ile Tip2'ye spesifik Plyc2 (F:5'-CTGTAACATTGGGGGCTGGT-3' R:5'CGATGCCAGAACCAAGAG AT-3') primerleri kullanılmıştır. PCR protokolü $94^{\circ} \mathrm{C}^{\prime}$ de iki dakikalık denatürasyon, 35 döngü olacak şekilde $94^{\circ} \mathrm{C}^{\prime}$ de 30 saniye, $62^{\circ} \mathrm{C}^{\prime}$ de 30 saniye, $72^{\circ} \mathrm{C}^{\prime}$ de 1 dakika, ve son olarak ise $72^{\circ} \mathrm{C}^{\prime}$ de 7 dakika olarak ayarlanmıştır.

\section{Izolatların virülensliklerinin belirlenmesi}

Patojenisite testinde, önceki çalışmalarda kullanılmış ve Bayraktar ve Oksal (2011) tarafından P. lycopersici'ye hassas olduğu bildirilmiş $\mathrm{H}-2274$ domates çeşidine ait tohumlar kullanılmıştır. Patojenisite testi, Fiume ve Fiume (2008)'ün bildirdikleri kültür filtrate yöntemi modifiye edilerek gerçekleştirilmiştir. Bu yönteme göre; tohumlar önceden \%1'lik sodyum hipoklorit çözeltisi ile yüzey dezenfeksiyonuna tabi tutulmuş ve 3 kez steril saf su ile durulandıktan sonra içinde kurutma kağıtları bulunan Petri kaplarına aktarılmış ve $25 \pm 1^{\circ} \mathrm{C}$ 'de çimlenmeye bırakılmıştır. Çimlenen tohumlardan her bir bitki, kotiledon yaprak dönemindeyken, içerisinde $P$. lycopersici'ye ait kültür filtratı bulunan test tüplerine aktarılmıştır. Bir kısım bitki ise steril saf su ve PDB içeren test tüplerine aktarılmış ve kontrol olarak saklanmıştır. Daha sonra domates bitkilerini içeren test tüpleri $25 \pm 1^{\circ} \mathrm{C}^{\prime}$ de 15 gün süreyle 12 saat aydınlık 12 saat karanlık ortamda bekletilmiştir. Inokulasyondan 15 gün sonra bitkilerde oluşan kök simptomlarına bakılarak 0-4 skalası kullanılarak hastalık indeksi değerleri kaydedilmiştir. Bu skalaya göre; $0=$ gözle görülen simptom yok, 1= kökün uç kısmında nekroz oluşumu var ve nekroz kök yüzeyinde \%25'ten az yayılma göstermiş, 2= nekroz kök yüzeyinin \%26-50'sini kaplamış, 3= nekroz kök yüzeyinin \%51-75'ini kaplamış, 4= nekroz kök yüzeyinin \%76-100'ünü kaplamış ve ölü bitkiler. Daha sonra hastalık indeksi değerleri aşağıdaki McKinney indeksi formülü (McKinney, 1923) kullanılarak 0-100 arasında hastalık şiddeti değerlerine dönüştürülmüştür.

$$
I=\frac{\sum(f . v)}{N . X} \cdot 100
$$

Formülde; $f$ = skala değerine giren bitki sayısı, $v$ = bitkilerin bulunduğu skala sayısı, $N=$ gözlem yapılan bitki sayısı, $X=$ en yüksek skala değerini göstermektedir.

\section{Istatistiki analiz}

Patojenisite sonucunda elde edilen ve McKinney indeksi formülüyle hastalık şiddetine dönüştürülen değerler SPSS Statiscis 22v bilgisayar programı kullanılarak varyans analizine (ANOVA) 
tabi tutulmuş ve Duncan testi kullanılarak çoklu karşılaştırma testine tabi tutulmuştur.

\section{Bulgular ve Tartışma}

2015 yılı yaz ve kış aylarında, Hatay illi'ne ait örtü altı ve açık alanda domates yetiştiriciliği yapılan Antakya, Arsuz, Samandağ, Serinyol ve Kırıkhan'da bulunan tarla ve seralarda survey çalışmaları gerçekleştirilmiştir. Tarla ya da seranın en az üç farklı yerinden örneklemeler yapılarak birbirinden en az 10 metre mesafede hastalıklı bitkiler gözlemlenmiştir. Arazi çalışmaları sırasında örnek alınan bitkilerde genel olarak solgunluk, sararma, yaprak dökümü, kök boğazında çatlama ve kahverengileşme ile kök bölgesinde kahverengi çürüme görülmüş olup bu tarz belirtiler gösteren domates bitkilerinin kök ve kök boğazını içerecek şekilde örnekler alınarak plastik poşetlere koyulmuş, etiketlendikten sonra buz kutusuna alınarak izolasyon işlemi gerçekleştirilene kadar $+4{ }^{\circ} C^{\prime}$ de saklanmıştır.
Yapılan izolasyonlada Fusarium oxysporum, F. solani, Fusarium sp., Macrophomina phaseolina, Rhizoctonia solani, Phythium sp., diğer bazı funguslar da tespit edilmiştir. $P$. lycopersici'ye benzeyen koloniler alt kültüre alınarak tek spor izolatları elde edilmiş ve saf koloni halinde saklanmıştır. Toplam 17 izolat, Schneider and Gerlach (1973)'ın önermiş oldukları morfolojik özellikler esas alınarak $P$. lycopersici'olarak tanımlanmıştır (Çizelge 1). İzolatların çoğu yavaş gelişme göstermiş olup 1 aydan sonra piknit oluşumu gözlenmiştir. Pekçok izolatın piknit oluşumunu tamamlamasının 60 gün kadar sürdüğü tespit edilmiştir. Daha önce dünyanın pek çok yerinden rapor edilen bu fungus Ozan ve Maden (2004) ve Bayraktar ve Oksal (2011) tarafından Ankara ve çevresinde bulunduğu bildirilmiştir. Yapılan bu çalışma ile $P$. lycopersici Hatay ilinde yetiştirilen domates bitkilerinde ilk kez tespit edilmiştir.

Çizelge 1. P. lycopersici'nin elde edildiği lokasyonlar, oluşturduğu hastalık şiddeti değerleri ve moleküler tipler

\begin{tabular}{cccc}
\hline İzolat Kodu & Lokasyon & Hastalık Şiddeti & Moleküler Tip \\
\hline TmPI1 & Antakya & $85^{1} \mathrm{~b}^{2}$ & 2 \\
TmPI2 & Antakya & $90 \mathrm{ab}$ & 2 \\
TmPI3 & Antakya & $85 \mathrm{~b}$ & 2 \\
TmPI4 & Antakya & $80 \mathrm{c}$ & 2 \\
TmPI5 & Arsuz & $80 \mathrm{c}$ & 2 \\
TmPl6 & Arsuz & $65 \mathrm{e}$ & 2 \\
TmPI7 & Arsuz & $65 \mathrm{e}$ & 1 \\
TmPl8 & Kırıkhan & $80 \mathrm{c}$ & 2 \\
TmPI9 & Kırıkhan & $95 \mathrm{a}$ & 2 \\
TmPl10 & Kırıkhan & $95 \mathrm{a}$ & 2 \\
TmPI11 & Samandağ & $80 \mathrm{c}$ & 2 \\
TmPl12 & Samandağ & $85 \mathrm{~b}$ & 2 \\
TmPl13 & Samandağ & $85 \mathrm{~b}$ & 1 \\
TmPl14 & Samandağ & $80 \mathrm{c}$ & 2 \\
TmPl15 & Serinyol & $75 \mathrm{~cd}$ & 2 \\
TmPl16 & Serinyol & $70 \mathrm{~d}$ & 2
\end{tabular}

${ }^{1}$ Rakamlar, hastalık indeksi değerlerinin McKinney formülü kullanılarak dönüştürülmesiyle elde edilmiştir.

${ }^{2}$ Farklı harfler ile gösterilen rakamlar Duncan çoklu karşılaştırma testi sonucunda istatistiksel olarak farklı bulunmuştur.

İzolatlara ait DNA'lar DNeasy Plant Mini Kit (Qiagen) kullanılarak extrakte edilmiştir. Tüm izolatlara ait DNA örnekleri PCR'da kolaylıkla çalışılabilir olup, bu sonuç $P$. lycopersici için kullanılan bu yönteminin elde edilecek DNA'nın kalite ve miktarı konusunda güvenilir olduğunu göstermektedir. Moleküler yöntemle teşhis amacıyla morfolojik olarak $P$. lycopersici olduğu düşünülen izolatlar arasından temsili bazı izolatların fungal rDNA'larına ait ITS bölgesi ITS1 ve ITS4 primerleri kullanılarak çoğaltılmış ve ardından moleküler yöntemle de teşhis edilmişlerdir. Temsili izolatların AY649590 Genbank erişim numaralı izolata \%97-99 oranında benzerlik gösterdiği belirlenmiştir. Daha sonra tüm izolatlar için P1yc1 ve P1yc2 F/R primerleri kullanılarak spesifik PCR işlemi gerçekleştirilmiş ve $17 P$. lycopersici izolatının 3'ünün Tip1, 14'ünün ise Tip2 olduğu tespit edilmiştir. Moleküler tip belirleme amacıyla kullanılan P1cy1F/R primerinin 147 bp, P1yc2F/R primerinin ise 209 bp uzunluğunda fragmentler oluşturmuştur. Oluşan fragment uzunluklarının önceki bazı çalışmalarda bildirilenlerle (Bayraktar ve Oksal, 2011; Infantino ve Pucci, 2005) uyumlu 
olduğu görülmüştür. P. lycopersici'nin moleküler tiplerine yönelik dünyada bazı çalışmalar gerçekleştirilmiş ve patojenin her iki tipinin de aynı bölgede bulunabildiği tespit edilmiş ve bu çalışmalarda Tip2'nin baskın olduğu bildirilmiştir (Infantino ve Pucci, 2005; Bayraktar ve Oksal, 2011; Infantino ve ark., 2015). Yapılan bu çalışmada ise izolatların \%17,66'sı Tip1 iken \%82,35'inin ise Tip2 olduğu tespit edilmiştir. Önceki çalışmalar ve bizim sonuçlarımız birlikte göz önüne alındığında $P$. lycopersici'de moleküler tip2'nin daha yaygın olduğu görülmektedir.

Yapılan patojenisite çalışmalarında izolatların tamamın domates bitkilerinde hastalık oluşturduğu tespit edilmiştir. İzolatlara ait hastalık şiddeti değerlerinin 65-95 arasında değiştiği gözlenmiş ve oluşturdukları hastalık şiddeti bakımından farklılıkların bulunduğu tespit edilmiştir. En yüksek hastalık şiddetini TmPI9 ve TmPI10 (95) oluştururken en düşük hastalık şiddeti değerini TmPI6 ve TmPI7 (65) kodlu izolatların oluşturduğu tespit edilmiştir. Yapılan Duncan çoklu karşılaştırma testinde ise izolatlar, hastalık şiddeti bakımından 7 farklı grupta toplanmıştır ve hastalık şidddetleri arasındaki farklılığın istatistiki olarak önemli $(P \leq 0,05)$ olduğu tespit edilmiştir (Çizelge 1$)$.

\section{Sonuç ve Öneriler}

Bu çalışma ile Hatay ilinde $P$. lycopersici izolatlarının virülenslik düzeylerinin farklılıklar gösterdiği tespit edilmiştir. Yine önceki bazı çalışmalarda izolatların oluşturdukları hastalık şiddetinin farklılıklar gösterdiği bildirilmiştir (Infantino ve Pucci, 2005; Bayraktar ve Oksal, 2011; Infantino ve ark., 2015; Fiume ve Fiume, 2008) ancak bu çalışma Hatay ilinde domates yetiştiriciliği yapılan alanlardan elde edilen $P$. lycopersici izolatlarının virülenslik düzeylerinin farklılıklarını tespit eden ilk çalışmadır. İzolatların iller bazında hastalık şiddeti ortalamalarına bakıldığında, Kırıkhan'dan elde edilen izolatların daha virülent oldukları (90) ancak Samandağ (85) ve Antakya (80)'dan elde edilen izolatların hastalık şiddetlerinden istatistiksel olarak farklı bulunmadığı $(P \geq 0,05)$ tespit edilmiştir. Diğer taraftan Arsuz ve Serinyol'dan elde edilen izolatların virülentliğinin daha düşük (70) görülmüştür (Şekil 1). Bu çalışma ile $P$. lycopersici izolatlarının virülenslikleri ile lokasyonlar arasında bir bağlantının bulunduğu tespit edilmiştir. Dünyada ve Türkiye'de etmenin virülensliğiyle ilgili yapılmış bazı çalışmalar mevcut olmasına karşın lokasyon ile virülenslik arasındaki bağlantıyı gösteren başka bir çalışmaya rastlanmamıştır.

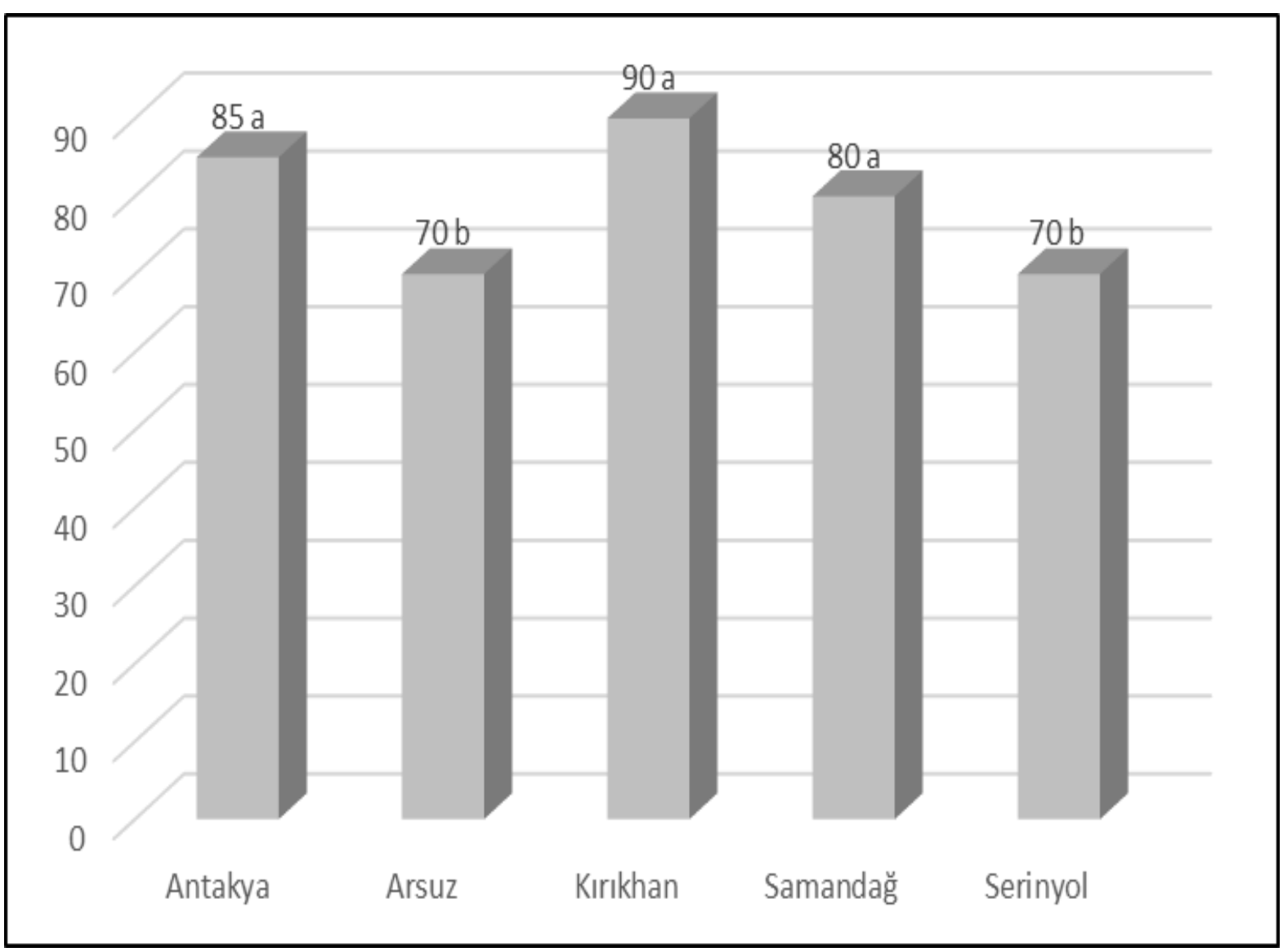

Şekil 1. P. lycopersici'nin ilçeler bazında oluşturduğu hastalık şiddeti ortalamaları. 


\section{Kaynaklar}

Bayraktar, H., Oksal, E. 2011. Molecular, physiological and pathogenic variability of Pyrenochaeta lycopersici associated with corky rot disease of tomato plants in Turkey. Phytoparasitica, 39: 165-174.

Cabi and Eppo, 2019. Distribution of Plant Diseases. http://cabweb.org/Pnt-Dis/plndipub.htm.

Carling, D.E., Summer, D. R. 1992. In Methods for Research on Soilborne Phytopathogenic Fungi, Eds: (Singleton, L.L., Mihail, J.D. and Rush, C.M), pp. 157-165.

FAO, 2017. www.fao.org.

Fiume, G., Fiume, F. 2008. Biological control of corky root in tomato. Common Applied Biological Sciences, 73(2): 233-248.

Goodenough, P.W., Maw, G.A. 1973. Effects of Pyrenochaeta lycopersici infection on nutrient uptake by tomato plants. The Annals of Applied Biology, 73: 339-347.

Grove, G.G., Champbell, R.N. 1987. Host range and survival in soil of Pyrenochaeta lycopersici. Plant Disease, 71: 806-809.

Infantino, A., Pucci, N. 2005. A PCR-based assay for the detection and identification of Pyrenochaeta lycopersici. European Journal of Plant Pathology 112: 337-347.

Infantinoa, A., Pucci, Aragonaa, M., Felicea, S., Raub, D. 2015. Genetic structure of Italian populations of Pyrenochaeta lycopersici, the causal agent of corky root rot of tomato. Plant Pathology, 64: 941-950.

McKinney, H.H. 1923. Influence of soil temperature and moisture on infection of wheat seedlings by Helminthosporium sativum. Journal of Agricultural Resources, 26: 195-217.

Nicola, S., Tibaldi, G, Fontana, E. 2009. Tomato production systems and their application to the tropics. Acta Horticulture, 821: 27-34.

Pohronezny, K.L., Volin, R.B. 1991. Corky Root Rot. In: Jones JB, Jones JP, Stall RE, Zitter TA, eds. Compendium of Tomato Diseases. St Paul, MN, USA: APS, 12-3.

Retig, N., Rabinowitch, H.D., Cedar, N.A. 1973. Simplified method for determining the resistance of tomato seedlings to Fusarium and Verticillium wilts. Phytoparasitica, 1(2): 111-114.

Richmond, K. 1992. CMI Distribution Maps of Plant Diseases. Common Wealth Mycological Institute Press, Germany.

Rowe, R.C., Miller, S.A., Riedel, R.M. 1995. Late Blight of Potato and Tomato. Ohio State University Extension. Extension Fact Sheet HYG-3102-95.

Schneider, R., Gerlach, W. 1966. Pyrenochaeta lycopersici nov. spec., der Erreger der
Korkwurzelkrankheit der Tomate. Phytopathologische Zeitschrift 56: 117-122.

Sherf, A.F., MacNab, A.A. 1986. Vegetable Diseases and Their Control. 2nd edn. John Wiley \& Sons, NY, 1115.

Tamietti, G., Valentino, D. 1990. A semi-selective medium for the isolation of Pyrenochaeta lycopersici from soil. Phytopathologia Mediterranea, 29: 90-94.

TÜiK, 2019. http://www.tuik.gov.tr.

White, J.G., Scott, A.C. 1973. Formation and ultrastructure of microsclerotia of Pyrenochaeta lycopersici. The Annals of Applied Biology, 73: 163-166.

Workneh, F., Bruggen, A.H.C., Drinkwater, L.E., Shennan, C. 1993. Variables associated with corky root and Phytophthora root rot of tomatoes in organic and conventional farms. Phytopathology, 83: 581-589.

Young, P.A., Harrison, A.L., Alstatt, G.E. 1940. Common diseases of tomatoes. Tcx. Agr. Expt. Sta. Cir., 86: 32. 